\title{
Epilogue
}

\section{Pawnshops as Stages of the Colonial Performance of Power}

I

N JANUARY 1922, the sudden outbreak of a strike among indigenous employees of the government's pawnshop service sent shockwaves throughout colonial society. Fearing that the strike would spread to other government services, the authorities brought in strikebreakers and fired all picketers. A political cartoon published in the sensationalist colonial weekly De Zweep (The Whip) showed two indigenous strikers clad in modern outfits-shoes, trousers, dress shirts, ties, jackets, pocket squares, hats, canes, and a cigarette in each of their mouths-while a strikebreaker passed by wearing a traditional sarong, kebaya, and Javanese headdress (blangkon). The cartoon further reinforced the juxtaposition between the characters in the accompanying text, as the two strikers expressed their amazement at the strikebreaker's appearance and behavior, noting with disdain that he was dressed as a common native, seemingly willing to carry teacups to the auction hall like a lowly servant. The protestors' ostensibly misplaced arrogance, smugness, indifference, and laziness are positioned in sharp contrast to the calm, honorable, and submissive strikebreaker. The cartoon perfectly captures the essence of the performance of power, showing both how Indonesians successfully subverted colonial hegemony by changing their appearance and the Dutch attempt to restore their formerly dominant worldview through ridicule and mockery. As such reactions make clear, incidents like strikes were not merely about improved working conditions but also about the changing character of the colonial relationship more broadly. Although the causes for the pawnshop strike of 1922 were not straightforward, being treated with more dignity and respect was among strikers' primary objectives. ${ }^{1}$

Like the numerous other sites of colonial encounters discussed in this bookfrom the civil service and private households to fairs, roadways, and railroad stations-pawnshops were important stages for the performance of power on which both colonized and colonizer actively communicated, expressed, and contested the discourse of colonial hegemony. In fact, the history of the pawnshop service in colonial Indonesia aptly encapsulates the various "acts" of this performance as outlined in this study. Pawnshops initially reinforced the Javanization of colonial authority, turned into spaces of its contestation around 1913, and ultimately played an important role in the forging and enactment of new modern 


\section{DE PANDHUISSTAKING}
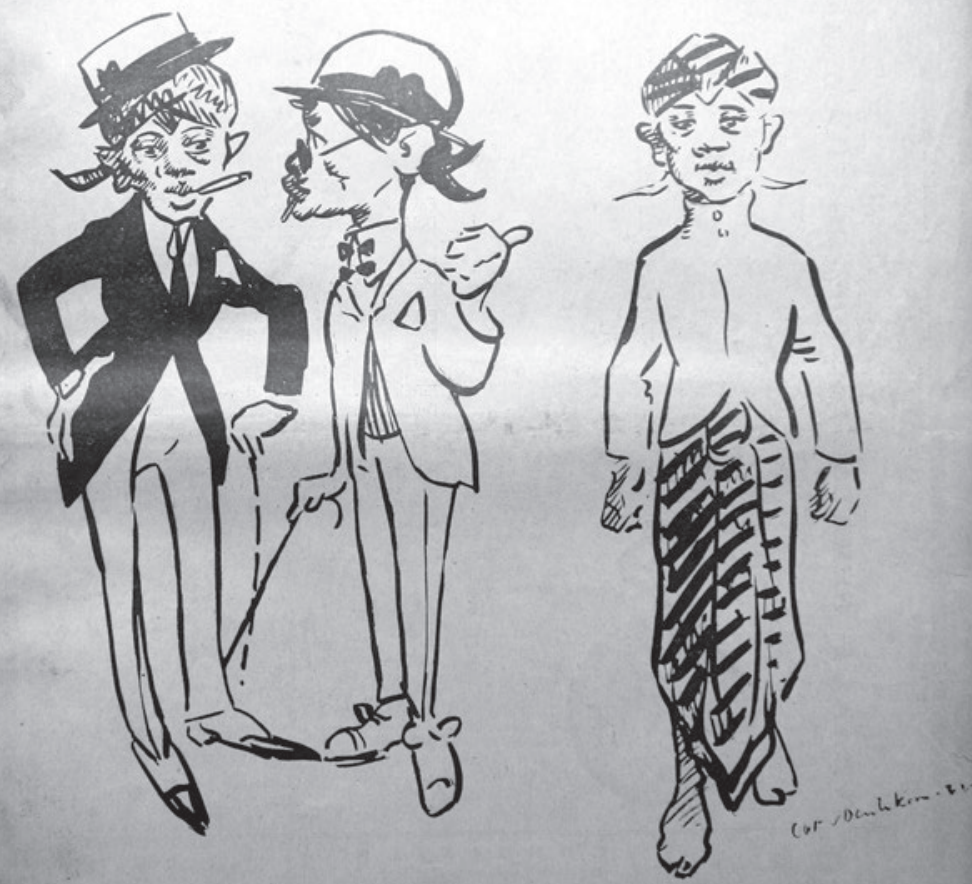

(De Iste stakende pandhuis-beambte): Wah zè̀ moet-ie die gemeene vènt zien. Onderkruiper, ż̀̀g, hii is zoo gek om zelf thee-kopies naar de veiling-loods te dragen.

(De 2de dito): Wah, snèr-vènt! Kiik maor naar züin kleerren; hï loop rond als gewoon inlander !

FIGURE IO. "The Pawnshop Strike." This cartoon effectively contrasts the noble and submissive attitude of the strikebreaker, donning traditional dress, with the misplaced arrogance of the striker clad in a suit. Source: De Zweep, January I5, 1922.

identities. Each of these acts demonstrates that through language, etiquette, appearance, material symbols, and attitudes, the Dutch tried to confirm and strengthen colonial hierarchies of race, class, and gender, while the colonized destabilized them through discursive everyday actions.

The first act of the colonial performance of power opens in the nineteenth century, when the Dutch sought to strengthen the legitimacy of the colonial state through collaborating with the priyayi and by adopting local deference etiquette, symbols of power, sartorial hierarchies, lifestyles, and architecture. 
Through the Javanization of colonial authority, as I call this deliberate process of acculturation, the Dutch attempted to instill a sense of compliance throughout the colonial populace. The hegemonic script for the colonial encounter was never static, however, but was continuously adapted to changing circumstances. For instance, as the priyayi lost influence in actual governance vis-à-vis European officials, the Dutch compensated them with additional symbolic vestiges of power. As the character of colonialism itself began to change-in part due to new insights in evolutionary science, the privatization of the colonial economy, and the rise of Japan and the United States as new imperial powers in Southeast Asia-the Javanization of authority seemed increasingly inadequate. In response, the Ethical Policy (announced in 190I) proclaimed that the Dutch had a moral responsibility to "civilize" the colonized, producing a new hegemonic script that divided colonial officialdom. While some agreed with the necessity of Dutch tutelage and Western examples, others believed that "civilizing" the colonized was an impossible task and that maintaining Javanized colonial rule was the only way to keep the peace. Consequently, there emerged a discrepancy between emancipatory theory and conservative practice.

The ambiguity of this first act of the colonial performance is strikingly reflected in the establishment of the pawnshop service in 1904. The Dutch ostensibly sought to use the pawnshop service to protect the colonized against the supposed abuses of Chinese middlemen. On the one hand, ordinary Javanese used government pawnshops for easy access to cash; on the other, the pawnshop service provided several thousand Javanese with coveted government positions. Employment in this sector essentially represented admission into the priyayi class of aristo-bureaucrats, since those who joined as administrators, appraisers, tellers, and clerks were mostly recruited from the grey area between the lower priyayi and the common people. As a symbol of their newly acquired social status, pawnshop employees were granted the right to carry a payung in $1906 .^{2}$ Although the government had prohibited the payung for European officials in 1904 as part of the attempt to modernize the colonial relationship, it continued to rely on the Javanization of authority by incorporating indigenous pawnshop personnel into the payung hierarchy. Just as in colonial society more broadly, these contrasting signals caused considerable tension among indigenous and European pawnshop personnel.

Pawnshops remain a key site for explicating the second act of the colonial performance, in which the sudden proliferation of everyday discursive challenges to colonial power in I9I3 signaled a broad social transformation-the Indonesian national awakening. Although most pawnshop workers were not 
necessarily highly educated, they did (or aspired to) belong to the new generation of Indonesians that articulated their desire for equality and respect in the vernacular press and in cultural and political associations. It is therefore no surprise that following the distribution of the hormat circular in August 1913 (which prohibited European officials from requiring traditional deference from the colonized), indigenous pawnshop personnel were among the first-along with teachers, physicians, railroad employees, and civil servants - to demand the circular's immediate and complete implementation. They expressed their activist mentality through a change in appearance, substituting their Javanese sarong and kebaya for a Western suit in an attempt to evade European administrators' calls for traditional deference. Their superiors, however, did not budge willingly, as acquiescing to the circular would have been analogous to granting their indigenous employees' equal social status.

Alongside their contemporaries, pawnshop employees turned to the vernacular press to air their grievances. For instance, one author in the periodical Doenia Bergerak wrote that his European boss treated his staff like animals rather than human beings, insisting that they continue to sit on the floor in his presence and speak in accordance with the Javanese language hierarchy. ${ }^{3}$ But as reports like these demonstrate, the colonized resisted such treatment through publishing their transgressions in the vernacular press as well as everyday discursive acts, such as speaking Dutch, wearing trousers, or demanding a chair. In 1919, another pawnshop employee pledged in the newspaper Oetoesan Hindia that he refused to "speak Javanese, to crouch, or to make the sembah" any longer for his European bosses. ${ }^{4}$ Frustrated with the protracted struggle for emancipation within the pawnshop service, a representative of the indigenous pawnshop workers union declared that there was only one choice left: "To strike or to crouch!"s

The pawnshop service strike of 1922 must be understood within the context of this prolonged cultural struggle between colonizer and colonized. According to former Advisor for Native Affairs G. A. J. Hazeu, the strike was the result of Europeans' failure to "acknowledge and take account of the change of mentality among Indonesians." He wrote that, on the contrary, all expressions of emerging self-awareness among the colonized, as well as their roots, were willfully ignored. ${ }^{6}$ It is telling that the spark that ignited the strike was an incident at a pawnshop in Yogyakarta in which an employee refused to carry pawned items to the auction hall (as referenced in the political cartoon). As a member of the priyayi, he felt he should be exempt from performing menial labor, generally relegated to special servants, but recent spending cuts dictated that the task was now his responsibility. Angered by his refusal, his European superior fired him 
on the spot, setting in motion a chain of events that caused the strike to spread like wildfire over Java, ultimately encompassing a third of all pawnshop personnel. Despite this widespread fervor, the strike ended with an anticlimactic thud, as all the indigenous employees involved lost their jobs along with their priyayi status. ' Even so, the history of the pawnshop service strike illustrates how a broader and more conscious challenge to the colonial order emerged out of everyday struggles. This is an important revision to the prevailing narrative of the Indonesian national awakening - it was not just a movement incited by a small political elite from the top-down but one that also grew out of large social transformations from below.

The third act of the colonial performance of power opens in response to these profound changes around 1913. As it became clear that the Javanization of authority was unsustainable, the Dutch began to contrast their sense of their own modernity with the alleged backwardness of the colonized. This resulted in the propagation of a more European lifestyle in the colony along with increased fear of the degenerative influences of both the tropical climate and the colonized themselves. Similarly, while the colonized sought new identities as modern Indonesians - attempts that the Dutch ridiculed and feared-they worried about the negative influences of Western culture. The colonial performance of power continued as both sides negotiated colonial modernity to articulate their new identities. They again did so in the everyday colonial encounter, expressing and communicating their approaches to modernity through changes in social customs, sexual norms, culinary preferences, and consumer behavior.

Pawnshops perfectly capture the anxieties surrounding the performance of new modern identities. As the strike of 1922 shows, the Dutch clearly equated Indonesians' changing appearance, comportment, and attitude with their increased demands for emancipation, equal opportunity, and respect. Ironically, with the pawnshop service European officials found an institution that could potentially offset these changes by taking away precisely those items through which Indonesians signaled their modernity and equality - clothing, sunglasses, shoes, canes, umbrellas, cigars, and more. For instance, in response to an earlier strike in 1920, a colonial newspaper mockingly declared, "Thousands and thousands of workers know no road as well as that from their home to the pawnshop and back." The author's implication was clear: Indonesians trying to present themselves as something they were not-modern, civilized, and equal-would eventually be forced to sell their "luxury items" at the local pawnshop. Thus, the colonial mindset celebrated the pawnshop as an institution that corrected this co-optation and exposed people for who they really were: their native subjects. 
The political cartoon discussed above draws on this same dichotomy, as the artist associates an Indonesian in European dress with arrogance and indolence and one in indigenous dress with modesty and obedience.?

Perhaps surprisingly, Indonesians also considered pawnshops to be crucial spaces where costumes and props for the performance of new identities could be bought and sold. For instance, a 1940 political cartoon in the periodical Pandji Poestaka depicted an Indonesian man clad in a suit and peci (cap) hailing a taxicab to go see a movie in the first-class section-all privileges associated with European or elite status (see figure 7). As to how he could afford these luxuries, the reader learned that, in fact, he could not; he had spent too conspicuously and was forced to pawn his suit and other belongings at the local pawnshop. But while seemingly similar to Dutch political cartoons, the message here is significantly different. Whereas the Dutch saw the pawnshop as an institution that exposed indigenous people's backwardness, Indonesians viewed these spaces as moral scales that weighed and judged modern vices within this changing cultural context. The cartoon's caption reminded the reader that it was important "not to forget where you come from," warning not against Indonesian modernity but rather against the dangers of excessive westernization and conspicuous consumption. ${ }^{10}$ Pawnshops were thus spaces that facilitated the condemnation of uncontrolled Dutch mimicry, and cartoons like this encouraged readers to filter their modern identities through indigenous cultural and religious traditions and to retain only the beneficial elements of Western modernity. If one failed to do so, a visit to the pawnshop was inevitable.

Tracing the development and evolution of the performance of power in colonial Indonesia thus uncovers a dynamic and engaging history of Indonesian agency and resistance. It brings into sharp focus the myriad ways in which power was continuously communicated and contested through a complex array of social performances and material culture in the everyday colonial encounter. Rather than privileging outright forms of political resistance, this emphasis expands the Gramscian concept of cultural hegemony and suggests new ways to analyze the interplay between culture and power. The value of this approach is not limited to Indonesian history or colonial societies, but by emphasizing people's decisions and lived experiences in seemingly unexceptional interactions, extends to the study of social relationships more broadly.

Japan abruptly put an end to Dutch colonial rule in Indonesia in 1942 , but the performance of power persisted into the postcolonial era. ${ }^{.1}$ While this larger history lies outside the scope of this book, dress remains an illustrative example of the perpetual nature of the hegemonic struggle. Changes in appearance 
continued to play a crucial role in the performance and contestation of power. Following the trauma of Japanese occupation (1942-1945) and the Indonesian revolutionary war (1945-1949), President Sukarno sought to strengthen national identity and unity through the creation of a pan-Indonesian batik design. The design reflected his attempt to appease various political and religious movements - foremost among them nationalists, Muslims, and communists—as well as to bridge the many regional and ethnic divisions in the newly independent country. While Sukarno succeeded in promoting Indonesian batik, the country was nonetheless torn apart in 1965 and 1966 by mass violence targeting communists. It was in the wake of mass murder that Indonesian leadership once more turned to dress to restore unity and national identity. In 1972, Governor Ali Sadikin of Jakarta was the first to encourage and popularize open-collar batik shirts for men, instead of Western dress shirts and jackets. President Suharto embraced this new style and commissioned a special batik shirt as formal wear for civil servants, thus reinstating batik as a symbol of state power. Through this initiative, batik was also reintroduced into Indonesian men's wardrobes without giving up their trousers-a design element that rendered batik representative of Indonesian modernity. Discussions of outward appearance did not end here; they continue today in debates over headscarves for women. The persistence of this and other topics of routine significance is a stark reminder that the performance of power-as well as its contestation-endures into the twenty-first century. 
